\title{
SOCIAL MEANING OF CULTURE IN A STALINIST PRISON CAMP
}

\author{
Aimar Ventsel, Baurzhan Zhangutin, Dinara Khamidullina
}

\begin{abstract}
The Stalinist prison camp system - popularly known as the Gulag archipelago - existed for a relatively short period (from 1931-1960) and became world famous as a synonym for terror, humiliation and human suffering. This article focuses on the social significance of culture in one of the biggest Stalinist prison camp - Karlag in Central Kazakhstan. The first part of the article gives an overview of the institutions of culture in prison camps and their activities. It also gives an overview of unofficial cultural activities and the consequences of being engaged in the unsanctioned creation of art. In the second part of the paper, the social significance of culture in Stalinist prison camps is discussed. Official and non-official art were not separate and existed in symbiosis: people crossed the border between these spheres. Moreover, the camp administration recognised the material value of art produced in the camp and began to organise the production of pictures or handicrafts in order to sell them outside the camp. Nevertheless, both official and unofficial cultures had a deep social meaning for the people. Producing unsanctioned paintings and other objects of artistry can be seen as an act of resistance, producing sanctioned art helped the artists to create their own social and mental space and distance themselves from the everyday grind of the camp. In general, culture and its institutions in the prison failed to fulfill their original purpose - instead of re-educating and changing inmates, culture helped to maintain human dignity and integrity.
\end{abstract}

Keywords: Kazakhstan, Gulag, social significance of culture

Stalinist prison camps are infamous and their existence is now well known all around the world. These camps are correctly associated with inhuman living conditions, suffering, slave labour, humiliation, tragedy, hunger and death. One influential work in disseminating the scenes and images of suffering, which made the abbreviation Gulag famous is the "Archipelago in Gulag", a book that has been translated into multiple languages (Solženitsõn 1990). However, "The Gulag Archipelago" and several other popular or academic books written about the Stalinist prison camps focus strongly on the injustice and inhuman conditions of this repressive system and touch lightly, if at all, on other aspects of the structure and how the Gulag functioned. The Gulag was a very complex institution and taking a closer look at the nature of the Gulag it is impossible to ignore 
the controversial ideologies and practices that were inherent in their structure. The aim of this article is to analyse culture and artistry in the Stalinist prison camp system. More precisely, the cultural institutions, the formal and informal cultural life as well as the artistic practices in one of the biggest camps, Karlag in Kazakhstan. It is hard to believe that there could have existed anything like "culture" in these camps, so much about the Gulag has become a synonym for terror, tragedy and death. However, the culture and cultural institutions in Stalinist prison camps were as complex and controversial as the whole system. The controversy was caused by different motivations and practices involving people engaged in culture within the camps. As will be demonstrated, formal and informal cultural practices were interwoven, instrumentalised and even commercialised in the Gulag system, processes that seem extremely unsuited for the image associated with such an institution. This article does not presume to be a complete analysis of the culture and the institutions of the Gulag.

This article draws on information from different sources. Some research was undertaken in Almaty in the Presidential Archive, Central Archive of the Republic of Kazakhstan and in several regional archives by Dinara Kamidullina and Baurzhan Zhangutin. Additionally, in April and May 2012, interviews were conducted with three groups of Estonians who were arrested in 1951-1952 and sent to Karlag where they stayed until the 1954 amnesty. More research followed in the National Archive of Estonia in Tallinn during the same period from April to May 2012. The authors of this article also relied on published sources on the everyday life and history of Karlag. Valuable information with biographies and memories of prisoners was also found in a volume about the art and culture in Karlag (Dulatbekov 2009).

One of the best known books written on the Stalinist prison camp system is "Gulag: A History" by the journalist Anne Applebaum (Applebaum 2003) but there is a longer tradition among historians to study the institution (the Gulag in general and Karlag in particular) by Western, Russian and Kazakhstan scholars. Today there are numerous academic publications on the Gulag that demonstrate the variety of topics associated with this institution. In general, studies on the Gulag appeared in the post-Soviet world only after the collapse of the Soviet Union. Several Russian academics' works explored new aspects of the topic focusing on the economy (Borodkin \& Gregory \& Khlevniuk 2005), children's camps (Gorcheva 1993) or legal aspects of prison camp policy (Ivanova 2006). For example, the monograph of Ivanova (2006) discusses the Gulag as a new type of Soviet penal system based on a complex analysis of laws, archival sources and financial accounting documents. In the West, the broad spectrum of archive material is published by Stettner (Stettner 1996), survival strategies of prisoners explored by Stark (Stark 2003) and the complex economic analysis 
of the Gulag is delivered by the edited volume by Gregory and Lazarev (Gregory \& Lazarev 2003). In Kazakhstan, the history and development of the Gulag has been widely covered by historians (Bastemieva 2008; Kukushkina 2002; Shaimukhanov \& Shamuikhanova 1999) also memories of former Gulag prisoners have come to light (e.g. Bakhtin \& Putilov 1994; Vaisberg 1991). However, most of the (semi)academic works written about the Gulag have been by historians. This paper is a combination of anthropology and history and our aim is to use anthropological concepts for discussing the cultural life and institutions of artistic production in Stalinist prison camps.

\section{THE CONTEXT: GULAG AND KARLAG}

A popular saying in Kazakhstan is that "Kazakhstan was the prison of the Soviet Union" (Kazakhstan byl tiur'moi Sovetskogo Soiuza). Indeed, the history and further development of Kazakhstan is closely linked to the penal system during the most infamous period of the Soviet Union - the period of the Stalinist regime. In the 1940s, the Soviet republic of Kazakhstan was peppered with a constantly growing network of prison camps concentrated around large central prison conglomerates like Karlag, Steplag and several others. One goal of the camp system was the appropriation of vast steppes of Kazakhstan (Barnes 2008) and some authors even argue that this policy was the main motivation behind the Stalinist purges - to create a free labour force to build industry and master territories (Gavrilova 2003). Moreover, the foundation for the multicultural society of Kazakhstan, with nearly 150 ethnic groups and 80 spoken languages (Perepis 2012), was laid in the era of the Gulag as many deportees or prisoners chose to stay in Kazakhstan after they were freed from the camps, even when movement restrictions were lifted. It must be noted that this period of Kazakhstan history cannot be separated from the general political and historical processes in the Soviet Union although its impact on the development of the region has been unique (e.g. Gavrilova 2003: 44).

The Gulag prison camp system was a product of several parallel developments in the Soviet Union (Gregory 2003). Here we would like to highlight two processes. The establishment of the Gulag took place simultaneously with the Soviet industrialisation project, where labour was required in huge quantities and often in very hostile and harsh environments (Gregory \& Lazarev 2003). Solzhenitsyn stressed in The Gulag Archipelago that the nature and intensity of work in the prison camps changed when the Gulag became a work camp and ceased to be a purely penal institution (Solženitsõn 1990: Vol II, Part III and IV). This period (1920s to 1940s) was also the era of Soviet nation building (a 
process based on terror and fear), where for ideological reasons a substantial mass of people needed to be isolated from mainstream society and - if possible - re-educated in order to fit into the new socialist order. These people were the 'remains' of the 'old order' (nobles, clerics), victims of the collectivisation, people who resisted Soviet ideology or annexation of new territories and people who did not participate in the building of the new state with the required enthusiasm (c.f. Gregory 2003: 4). It is generally agreed that the prototype for the future Gulag was the Solovki Camp of Special Destination (SLON) on the Solovetsky Islands in the White Sea, established shortly after the revolution (Barnes 2011; Gregory 2003; Solženitsõn 1990). After 1926, prisoners' labour was systematically used in forestry and fisheries (Gregory 2003: 9). Similar to Karlag and other Gulag prisons, SLON had its own newspaper - 'Solovetskie ostrova' (Solovetsky Islands) - distributed around the whole country (this was not the case with later Gulag penal colony newspapers). Solzhenitsyn argued, that at this time the state wished to demonstrate the existence of a prison camp that was a temporary place to isolate the 'alien element' to the new socialist society, an institution which would become useless as soon as the new Socialist state became established (Solženitsõn 1990: Vol II, 32).

On 6th of November 1929, the Central Executive Committee and the Council of People's Commissars passed a law that imprisonment of up to three years should be carried out in "regular prisons" whereas confinement from three to ten years should take place in prison camps in remote regions of the country (Prokopchuk 2004). The creation of a network of prison camps was begun. For management of the camp system the Gulag was created (Glavnoe upravlenie ispravitel'no-trudovykh lagerei, trudovykh poselenii $i$ mest zakliucheniia or the Main Administration of Labour Camps, Labour Settlements and Places of Detention) which was subordinated to the NKVD of the Soviet Union (Narodnyi Komissariat Vnutrennykh Del or People's Commissariat of Internal Affairs, a Soviet ministry for internal affairs). The Gulag controlled, in its heyday, 36 of the so-called "corrective-labour camps" (sing. ispravitel'no-trudovoi lager'), in fact each of these camps was a conglomerate of several prison camps (Dulatbekov 2010; Gavrilova 2003). On the 26th of March 1953 Lavrentii Beriia, the deputy prime minister of the Soviet Union at the time, reported to the Presidium of the Central Committee of the Communist Party of the Soviet Union (the highest institution of the Soviet Union de facto governing the country) that this year the number of inmates in the Gulag prison system was 2,526,402 people (Ivanova 2006). The existence of the prison camp system was quite short compared to the impact and legacy it left: The Gulag was officially closed on the 25th of January1960 (Ivanova 2006). Ironically, the idea behind the Gulag camps was to re-educate criminals and "enemies of the people" and put them back onto the 
"right track". Therefore, Gulag prison camps were not concentration or annihilation camps but were officially called corrective-labour camps (ispravitel'notrudovoi lager') and had a very specific ideological background: it was believed that through participation in socialist labour and the right cultural and political education, criminal and political prisoners could be turned into loyal Soviet citizens and re-enter society after their prison sentence. During the existence of the Gulag, the camps had various programmes and institutions whose existence made sense only in the light of the ideology of correction, re-education and re-integration of prisoners. However, a certain shift in the Gulag ideology took place after WWII. At the end of the 1940s in the territory of Kazakhstan several new prison camps were opened. In fact all the camps of the "strict regime" (sing. lager' strogogo rezhima) like "Stepnoi" (25,000 inmates), "Peschanyi" and "Lugovoi" (both for 15,000 inmates) were a complex of several smaller camps. These camps, especially Stepnoi or Steplag, had a structure similar to the Nazi concentration camps and it is argued that the inspiration for this new form of camp was derived from the Nazis (Shaimukhanov \& Shaimukhanova 1999: 164). The goal of these new camps was to extract natural resources with the lowest possible costs. In these camps, prisoners had a number instead of a name, i.e. "their names were taken away". Living conditions in the camps of the "strict regime" were especially miserable. In addition, these camps engaged in minimal "corrective" activities, if at all (Solženitsõn 1990: Vol II,Part V; Shaimukhanov \& Shaimukhanova 1999: 164).

Karlag or Karaganda Corrective-Labour Camp (Karagandinskii ispravitel'notrudovoi lager') was one of the biggest complexes of Gulag prison camps located in Central Kazakhstan, in the Karaganda Province (oblast) of the Kazakh SSR. It is estimated that during the existence of Karlag between 1931-1959 nearly one million people went through its camps and affiliates. On the 1st of October 1931 Karlag housed 12,174 inmates, in January 1941 - 51,404 inmates. The maximum number of inmates in Karlag was in January 1949 - 65,673 convicts ${ }^{\mathbf{1}}$. With the growth of convicts the camp complex increased as well and in 1952 included 64 male and 39 female zil'nye zony or living zones. ${ }^{2}$ Solzhenitsyn named Karlag "the biggest capital of the camp world" (krunpneishaia stolitsa lagernogo mira). Suffice to say, in Kazakhstan, camps included representatives of almost every ethnic group from the Soviet Union as well as Poles, Germans, Hungarians and people from other territories occupied by the Red Army: (Dil'manov 2002; Russkii... 1996; Shaimukhanov \& Shamuikhanova 1999). ${ }^{3}$ Karlag was an umbrella institution for 29 different subunit camps and - what makes Karlag different from other Stalinist camps - most inmates of Karlag were victims of the infamous 58th article, i.e. they were convicted for political crimes (anti-Soviet propaganda, counter-revolutionary activity, espionage for capitalist countries, 
etc.) as "enemies of the people" (Gavrilova 2003). After WWII political crimes also included collaboration with enemies or surrendering in war. Karlag stuck out in the Gulag system for its high concentration of so-called intellectuals: famous Soviet scholars, artists and doctors were imprisoned there. The most unique and infamous of the Karlag prison camps was prison camp No. 26, known as A.L.Z.I.R. - Akmolinsk camp for the wives of the traitors of the fatherland (Akmolinskii lager zhen izmennikov rodiny). It is argued that nowhere else in world history has a special camp for spouses of convicted political prisoners ever existed (Gavrilova 2003: 46; c.f. Shaimukhanov \& Shamuikhanova 1999).

The centre of the Karlag system was the state farm (sovkhoz) "Gigant". In fact, Karlag was organised to keep the state farm running. Karlag was established on the 19th of December 1931 when the state farm Gigant was reorganised into an enterprise based on forced labour (Gavrilova 2003: 8). ${ }^{4}$ The region around Karlag is rich in coal and the main purpose of the camp was to provide industrial workers with food. Karlag received 110,000 ha of land to cultivate and was engaged in a range of agricultural activities. With the industrialisation in Kazakhstan and growth of the convict labour force, the food requirements increased and the size of Gigant grew - the state farm in 1951 occupied approximately two million hectares of land. ${ }^{5}$ As Steven Barnes writes; "Karlag was primarily, though not exclusively, an agricultural camp established to transform the semi-desert of the steppe into a productive agricultural base for the provision of livestock and crops to the region's growing population engaged in the extraction of natural resources" (Barnes 2008). For that purpose, the administration of the camp deliberately selected its inmates by occupation with a preference for those with qualifications needed for the everyday work life in the camps and enterprises, i.e. engineers, farmers and construction workers, but also accountants, artists, and so forth (Gavrilova 2003: 45). Barnes argued that Karlag was an atypical penal colony for the Gulag (2011:3) due to its focus on agriculture and its high proportion of political prisoners. The structure of Karlag was constantly changing: before its closure on the 27th of June 1959 the camp had departments for political work, cadres for free labour, the 3rd department (security), a military security force, departments of accounting and distribution (of inmates), cultural-corrective work, administration and economics, supply, trading and finance, transport and inspection (Shaimukhanov \& Shaimukhanova 1999: 18). 


\section{IDEOLOGY AND CULTURE OF KARLAG}

When taking into account the popular image of the word Gulag as a place for death, misery and suffering, the idea that a cultural life existed in the camps sounds absurd. As surreal as it seems, Karlag strictly followed the ideology of a corrective labour camp. ${ }^{6}$ Kazakh researchers have formulated the ideology of Stalinist corrective labour camps on the basis of various rules and prescriptions that often bore strong ideological connotations (Bastemieva 2008; Dil'manov 2002; Vaisberg 1991). The prisoners should not feel isolated from Soviet society and had to be aware that they also participated in the economic processes while in the penal institution, i.e. the camp prisoners had to feel that they worked for their country. Therefore many camps introduced a five year plan, socialist labour competitions and supported the Stakhanov movement. ${ }^{7}$ The inmates were obliged to participate in the "cultural-educational work" (kul'turno-vospitatel'naia rabota) to remain in touch with the changes and new developments in Soviet society. Communists were of the opinion that this would enable prisoners to be more easily re-integrated into society after completing their sentence (Shaimukhanov \& Shaimukhanova 1999: 144).

In Karlag, as in the whole of the Gulag, there existed extensive structures with the task of organising and conducting cultural and re-educational work. These activities were officially called "political-re-educational work" (politikovospitatel'naia rabota) and responsible for that field were two departments the political department (politotdel) and the cultural-re-educational department (kul'turno-vospitatel'nyi otdel), subordinated to the Main Administration of Karlag (Upravlenie Karlaga). These departments were engaged in several activities that were called in typical Soviet manner, political-mass work (politiko-massovaia rabota) and industrial-mass work (proizvoditel'no-massovaia rabota), the first aimed to raise the political awareness of prisoners and the latter was supposed to motivate prisoners to participate enthusiastically in a socialist production process, i.e. to work harder and with better results. Apart from these activities, both departments supervised something called the "wall press" (stennaia pechat', wall desks filled with announcements and information), school work in camps, so called "club-mass work" (klubno-massovaia rabota), libraries and organised lectures. To cope with the task, an impressive number of facilities and personnel existed in Karlag. During its existence, the camp hosted 75 clubs and 26 stationary or mobile cinemas. The 85 libraries of the camp possessed 59.879 books (including 35.000 fiction books) ${ }^{8}$ and were subscribers to diverse newspapers and journals. In 1947 alone there were: 1,954 educational lectures, 10,404 political lectures (politdoklad), 87,747 collective newspaper reading sessions, 1,911 concerts and artistic performances, 1,300 
film shows, and 264 of the so called 'wall newspapers' (stennaia gazeta) were written in Karlag with the aim of "mobilising inmates to increase productivity and strengthen camp discipline" (Shaimukhanov \& Shaimukhanova 1999: 145). It should be mentioned that the statistics for 1950 were much higher. Hundreds of people worked in the cultural institutions of Karlag with the task of conducting and supervising events. Most of the cultural workers were recruited from among the inmates but dozens were also hired with a regular wage from outside of the Karlag. From the beginning of Karlag, in 1931, the camp newspaper "Putevka" (The Journey) was organised with ca. 6500 copies printed of every issue. The newspaper had 1125 "active camp correspondents" who regularly contributed news and stories from different subdivisions of Karlag (Shaimukhanov \& Shaimukhanova 1999: 148). In 1931, a Karlag boarding school opened, and in 1932 - a vocational school. The teachers were recruited among the educated inmates (Shaimukhanov \& Shaimukhanova 1999: 147-149). Looking at the numbers, the cultural and educational life in Karlag unexpectedly was blooming, a phenomenon which cannot be explained only by top-down initiatives and regulations.

Culture and artistry in this article is represented with a broad stroke. As will be demonstrated, practices that can be categorised as high, low, official, informal and commercial art and culture, were interwoven within Karlag. Therefore activities like handicraft, poetry, painting or making theatre decorations can be interpreted as different sides of artistry.

Several scholars have noted that in Karlag a number of well-known Soviet artists and scholars were imprisoned. A. Chizhevskii, the scholar and experimental artist, E. Olevshikova, an opera soloist from Kharkov, M.Ler, a former director of the Moscow operetta theatre, R.M. Ilisetskaia, a ballet dancer, P.P.Frinzen, a famous Soviet painter were among the artists and academics linked with Karlag (Gavrilova 2003: 50-54; Shaimukhanov \& Shamuikhanova 1999: 149,151). Alexandr Grigor'ev, the organiser of the artist association, Association of Artists of Revolutionary Russia (Assotsatsia Khudozhnikov Revoljutsionnoi Rossii), an organisation whose aim was - ironically - to support state ideology, spent several years in Karlag. In the Karlag archive there also exist files on the Leningrad graphist V.V.Lebedeva and the sculptor E.S.Ovoshhnikov, who established the art group Supporters of the new art. ${ }^{9}$ The policy of sending "intellectuals" to Karlag seems to be consistent throughout the existence of the camp. Artists and scholars were also sent to Karlag after WWII from the newly occupied territories. For instance, one of our Estonian informants mentioned that he met the well-known prima donna of the Estonian national opera, Gerta Murre, in Karlag (Interview 06.05.2012 in Tartu). Later famous Soviet Estonian avant-garde artist Ülo-Ilmar Sooster spent several years in one of the Karlag 
subdivisions. Karlag was also a forced home for several German artists, some of them from Germany, others from the Volga region (Gavrilova 2003: 8).

Any kind of unsanctioned art was forbidden in the prison camps. Scholars who studied the culture of Karlag and other Gulag prison camps have written that even the possession of pens and paper was punishable (Gavrilova 2003: 8). This regulation is also confirmed by our own archival research and interviews. There are numerous cases when people were punished for owning these items or when pictures they had drawn were found. It frequently happened that paper, pens, sometimes even handmade ink or colours were confiscated, and then followed by draconian punishments. For example, when guards found some black and white pictures made by the Estonian artist Ülo-Ilmar Sooster, they threw the pictures into an oven and beat the artist brutally. One of the guards kicked him in the face and breaking several of his front teeth. Interestingly, fellow inmates and the artist himself managed to save some of the pictures from the fire and these works with burned edges are now in the museum of Karlag in Karaganda (Gavrilova 2003: 77-78). As well as physical punishment, such violations included being locked up or transfer to a harder work detail. Nevertheless, despite the risks many prisoners engaged in drawing pictures, writing poetry or carving small items. Some of the Karlag prisoners even managed to keep diaries, another strongly forbidden activity. In most cases, to carry out such risky activities, prisoners were forced to create their own tools and hide them from the guards. It was not unusual that paintings were made using coal from the ovens. In order to make coloured pictures, artists invented complicated strategies. There are documented cases when prisoners boiled pieces of carpet or textile in order to prepare the colour for their paintings. One possibility to obtain colour was to use the blood of the dead dogs and cats that people managed to find. Moreover, people made brushes from the hair of dead animals.

As well as the "real" art, prisoners of Karlag participated in artistic handicraft. In the museum of A.L.Z.I.R. in Akmolinsk, tastefully decorated women's shirts, Ukrainian towels and other items made by convicts are exhibited. For the handicrafts, the source materials were also made by the women - for example by boiling threads in coloured water they produced red, yellow and various coloured flosses to embroider their clothes or towels. Prisoners also decorated their barracks and produced objects and items such as dolls, little sculptures and even ash trays, etc. some of which are exhibited in the museum of A.L.Z.I.R. (see also: Shaimukhanov \& Shaimukhanova 1999: 145-149).

The policy of the Karlag administration, the guards and various leading personnel of subunit camps towards diverse forms of art was very controversial and interesting. In the prison camps there existed several overlapping policies making non-sanctioned art not illegal but semi-legal. As mentioned above, 
pens and paper in the camps were forbidden and possession of these items was punishable. However, there were several cases when a camp administration tolerated and even supported these activities. Galina Semenova writes in her memoirs that as soon as the women in A.L.Z.I.R. had settled into the newly built camp and life attained some routine they asked the camp administration for the permission to decorate their barracks. With great enthusiasm they painted the walls white and decorated the oven and walls with portraits, folkloric pictures, plants and landscapes. One woman drew a picture: silhouettes of the Russian poet Pushkin in discussion with one of his best known heroes Evgenii Onegin standing on the river bank of Neva. The oven was repainted as a classic Dutch oven (Dulatbekov 2010: 240).

The enormous potential of so many artists and highly educated scholars in Karlag occurred to the camp administration. Initially, the skills of the artists were utlised in political-educational activity. Numerous theatres and clubs in the subdivisions of Karlag made use of the artists as actors, directors or decorators. ${ }^{10}$ Theatre plays were staged in large numbers, sometimes very complicated and even avant-garde (Gavrilova 2003: 60). This again demonstrates the controversy related to the Stalinist prison system. There is reliable documentation that proves the existence of experimental theatre under the nose of the Karlag administration. It seems that in the prison camp, the theatre, a barometer of artistic freedom, was broader than outside of the camps. The artists performed critical songs where they made jokes about camp officials and theatrical performances that would have been impossible to stage in an 'average' theatre due the fact that the authors, the themes, or the play itself was forbidden. Partly it was due to the ignorance of the prison censors who did not grasp the irony behind the plays or poems (Solženitsõn 1990), partly due to the weaker control in some Karlag camps where the officials and guards were also bored of living in isolated settlements far away from European Russia. However, again there is controversial evidence on how the activities in the prison camp theatres was organised. Memoirs of the prison camp theatre activities tell that artists had to make their own costumes, combining any materials they were able to find, other former prison camp theatre artists counteract that the administration did not count the money when they had to buy material for costumes: "If the plot needed a wolf skin coat then a wolf skin coat was bought" (Gavrilova 2003: 60 ). As grotesque as it may be to imagine hungry inmates performing plays in expensive costumes, this was one of the Gulag system's contradictions. Apart from theatre, prisoners were used as entertainers for various official music events. In general, state holidays were not celebrated in Karlag, so as to remind the inmates that they were behind the barbed wire and not free citizens. However, concerts and dances were organised to entertain the administration. For 
prisoners, concerts of patriotic songs or sometimes even classical music were organised as part of the political-corrective work (Gavrilova 2003; Shaimukhanov \& Shaimukhanova 1999).

In 1938, Karlag opened their 'artistic workshop' (khudozhestvennaia masterskaia) whose goal at the beginning was to provide the camp's theatres with costumes and decorations and design wall newspapers or blackboards with information and political or cultural articles (Shaimukhanov \& Shaimukhanova 1999: 46). In this workshop artists worked with different profiles and performed various tasks from sewing costumes to painting decorations. Pretty soon the workshop became a meeting place of likeminded people who gathered there to communicate and forget the camp's everyday life. The workshop soon became the institution that marked the commercialisation of art in Karlag. Many artists who directly worked in the workshop or were indirectly linked to it remember that soon after the opening of the workshop they started to receive requests to make paintings or other handicrafts for people. Guards, officials from the administration and fellow inmates ordered paintings, mainly portraits of their relatives. The camp administration used talented artists to decorate their homes with portraits of their wives and children or ordered pictures of landscapes and copies of well-known works of art. Also, fellow prisoners asked for paintings of their wives and children, prepared using photos they had received from home. The art and handicraft requests were produced with compensation, for example, prisoners paid with the little money or food they had in order to obtain these pictures (Dulatbekov 2010: 360-363; Shaimukhanov \& Shaimukhanova 1999: 66).

The art and handicraft produced by the workshop spread quickly outside of the camp and the prison camp administration decided to start marketing the produce. It became obvious that people in the nearby towns and villages were ready to pay money for decorative little items or pictures, and the workshop started to produce art to be sold in the markets and shops surrounding the camp. Slowly the art workshop changed from satisfying the internal demand of theatre decorations, wall newspapers and art produced for the staff, into an enterprise whose produce was sold outside of the camp system. This trade turned out to be so profitable that soon the workshop was turned into a self-accounting (khozrashchet) enterprise. The Karlag administration supplied artists with materials, bought different colours, paper, and brushes. There is very little evidence as to what degree the artists working in the workshop profited from their work, but it is obvious that preparing handicraft or pictures for money or food and producing art to be sold on the markets must have improved their living conditions and most importantly their diet. Moreover, having better access to food and/or money increased their social status. Despite the fact that 
people in the art workshop were convicts, they were excused from the general labour and enjoyed a relative freedom. According to Solzhenitsyn (Solženitsõn 1990), every position that made it possible to avoid heavy physical work was valued in the Gulag as a possibility to stay alive and survive until the end of the punishment period. In several memoirs, printed in overviews of Karlag, former convicts confess that they always looked for the possibility to join the art workshop brigade and therefore be engaged with physically lighter work. In summary, it could be argued that in the cultural world of the prison camp two different concepts of art existed-forbidden/illegal and semi-commercial sanctioned art (Dulatbekov 2010: 360-363; Shaimukhanov \& Shaimukhanova 1999: 66).

\section{ARTISTRY AS A SHADOW REALITY}

When looking at the blossoming official and unofficial cultural life in Karlag several questions arise. Why were people engaged in the forbidden artistry? Was participation in the official art voluntary or forced? Is it possible to look at people who entertained the camp's administration as theatre artists, or proponents of the propaganda that hailed the system that sent them to the camp and therefore collaborators with the Stalinist penal system? And the last question was the making of official sanctioned art purely a practical decision - to earn some money or food and to avoid the hard physical work - or was there more behind it? Fortunately there are several published sources (diaries, memoirs and so forth) that help to give an answer to these questions.

The case of decorating a female barrack was mentioned previously. Galina Semenova writes of the importance of this work, as drawing and painting pictures was an "escape from the darkness of the disaster in consolation of the spiritual pain" (vykhod iz mraka bedstvii utesheniem dushevnoi boli) (Dulatbekov 2010: 241). The purpose of art as a way to maintain an inner integrity, and to forget reality, is also mentioned by many former prisoners. Moreover, the creation of art as a means to avoid being broken by the prison system is highlighted by scholars (Dulatbekov 2009, 2010; Gavrilova 2003).

Olsen writes that material objects are related to bodily practices and creating objects is often a process of enacting cultural norms (Olsen 2010: 122). The process of drawing, painting or making handicraft was for prisoners often the only way to create another reality that left behind the barbed wire. It is remarkable how important these activities were for re-creating their personality. For example, it is argued that the uncompromising nature of Estonian artist Ülo-Ilmar Sooster was closely connected with his refusal to give up drawing, 
the artist followed the style of the Paris school that he had learned in his youth in Estonia (Dulatbekov 2009: 77-78). Tim Ingold argues that temporality is a selective way of interconnecting physical objects, events and histories (2000: 201-207). In the prison world, the artists re-created their pasts via activities and objects that connected them with the world before the prison camp. Using their creativity to transfer objects from their environment to tools to make art (using coal for drawing, boiling textiles to make colours, etc.) was a 'habit memory' (Olsen 2010: 117), an act re-establishing personalities and skills that belonged to another world and were often not supposed to exist in a prison camp. Applying the strategy of re-enactment and using skills or tools that belonged to "another world" can be seen as an act of resistance in a situation where prisoners were forgetting and ignoring the everyday. This way, Karlag prisoners were able to enter another temporality, an imagined reality that was juxtaposed to the reality, the world where they had no dignity or human rights. As several memoirs and documents show, several Gulag prisoners were keen to establish these temporary realities that reminded them of home and a life of freedom. These temporal spaces were physical (the art workshop) or created with tools (embroidering shirts) or through practices (singing, theatre, etc.).

The making of art was often a collective process to establish an alternative social bonding. Roksana Sats, whose mother was director of a camp theatre, was able to visit her in the camp. She recalls how her mother and her friends made colours from medicine they received from a camp doctor (Dulatbekov 2010: 290). Our Estonian informants told us how recitals of the choir gave them the possibility to withdraw, to forget the everyday life in the camp, speak Estonian to each other and sing Estonian songs (interview 06.05.2012). Collective engagement in the production of theatre plays helped people to escape from their role as a prisoner and temporarily transcend normality. This 'collective remembrance' (Jones 2003: 84) often included groups of people and attracted bystanders. Roksana Sats says that the prison camp actors, whose group also included a big number of female criminals organised sporadic dances when practicing for another theatre play (Dulatbekov 2010: 290). In the 1950s when the camp regime was loosened, Estonian prisoners in Karlag organised a brass orchestra and asked their relatives to send them instruments from Estonia (Dulatbekov 2010: 190; Kärp 1991: 96, 133; interviews in 06.05.2012 in Tartu). Dancing is part of the 'normal' world, emotionally linked to leisure, lack of problems and joy. Brass orchestras are traditional Estonian collectives, a firm part of the pre-war Estonian village culture. The orchestra not only linked musicians with their past and homeland but also confirmed their Estonian identity. The Estonian brass orchestra became popular and performed also outside of the camp, even in dances organised for Karlag officers in nearby settlements (Surva 
2010: 24). The success of the orchestra most likely re-asserted the dignity of the musicians, it was a demonstration that they were not inferior to the people who had the power to command them. ${ }^{11}$

Heidegger (Heidegger 1962) theorises how 'forgetting' (Vergessen) is a way of connecting the past and present. Solzhenitsyn recalls how prisoners sometimes gathered in the department of culture to forget their hunger and discuss art or philosophy, things that belonged to a "fairytale like past" (Solženitsõn 1990: Vol II, 364). In Karlag, forgetting was a strategy to establish a temporal and illusionary past. Several researchers and former prisoners have stressed the importance of the existence of the art workshop as a place to re-create 'normality'. The workshop was a space behind the closed door that was transformed into a place where 'one lifeworld replaced another lifeworld' (Olsen 2010: 115). Several like-minded people gathered regularly in the workshop to discuss, conduct academic lectures and spend time together. One prisoner recalls how they celebrated New Year's Eve in the workshop, 'as if the camp did not exist'. They decorated the workshop and drank tea and vodka (Dulatbekov 2010: 278). By using their income from official and unofficial artistry, prisoners were able to buy some sweets in the camp shop and have access to alcohol via the prison guards. This showed that hungry people were ready to spend their hard earned income on the celebration of holidays to recreate a home-atmosphere and not directly on food as one would expect. Heiddeger and Mulhall (Heidegger 1962; Mulhall 1996) write referring to the social meaning of material objects that every 'world' possesses an 'equipmental totality' which defines this lifeworld. There are objects that are associated with a certain environment and lifestyle and the other way around, certain objects can represent certain lifestyles or social groups. Material objects embody the order, norms and emotions of the social environment and by the change of lifeworlds, the 'equipmental totality' changes as well or objects shift their meaning. What happened this New Year's Eve in the workshop in Karlag was that by changing the 'equipmental totality', prisoners were able to change their 'world' for a short time.

\section{CONCLUSION}

Life in the camps was as controversial and complex as the Gulag system itself. Stalinist prison camps were definitely places of terror, injustice and human tragedy. However, the research shows how ideologically organised the life and inner structure of the corrective-labour camps was. According to the concept of 'corrective' policy and heavy ideological pressure, the camp prisoners were expected to become 'good citizens' via participation in the process of Socialist 
labour and cultural re-education. In the Gulag camps, there existed institutions whose direct task was to conduct ideological and cultural work among inmates. These institutions governed an impressive number of libraries, theatres, cinemas and even published the camp newspaper. Similarly, a large number of films were shown, also political and educational lectures, as well as theatre plays happened in these facilities. Even if we assume that some of these and other cultural events never took place and were just a manipulation of statistics, the formal and informal cultural life of the Gulag was nevertheless unexpectedly 'blooming', something hardly anyone associates with a prison camp.

Karganda Corrective-Labour Camp (Kargandinskii ispravitel'no-trudovoi lager') was one of the biggest complex of Gulag prison camps located in Central Kazakhstan of the Kazakh SSR. Karlag was, to some extent, an unusual Stalinist prison camp - it was established around the biggest state farm and was engaged with agricultural production, and a large number of prisoners were from the intelligentsia - actors, artists, musicians, but also people with a technical education. The work force for camp cultural institutions and activities was recruited from among these people. Ironically, it seems that ideological pressure and the censorship of culture was weaker inside the Stalinist prison camps than outside of them: there is evidence of avant-garde theatre productions in Karlag theatres. Another unexpected fact about Karlag was the commercialisation of culture: in 1938 there was an art workshop established whose task was not only to supply camp theatres with decorations or issue camp wall newspapers but also to produce handicraft and art to be sold outside of Karlag for money. The art workshop became a profitable enterprise and a shelter for various artists. Apart from the official art, in Karlag, there existed an unofficial non-sanctioned artistry. Possession of paper, pens and other tools for making art or keeping diaries was strictly forbidden and there is evidence of cruel punishments for people who violated that law. Nevertheless, several people were engaged in illegal art, some of the prisoners even started their artistic career in Karlag (like the Estonian artist Sooster).

The questions this paper poses are: what was the meaning of cultural life in Karlag and why were people engaged in these legal and illegal activities. Apart from residing in an institution of forced labour, with a limited option in choice of activities, handicraft and art were exercised to improve one's living conditions (for extra food and money) or to avoid harder physical labour. Nevertheless, there was little material gain and great risk was involved in practicing forbidden art. To explain the existence of all the varieties of artistry in Karlag, the social meaning of making art should not be ignored. The enthusiasm and passion that was related to producing official and unofficial art is related to the creation of a physical and mental space for people where they can withdraw and forget, at 
least, for a short time, the everyday life of a prison camp. As one theatre director told her daughter: "You can do theatre everywhere, even in a prison camp. Especially in the prison camp, you need to do theatre" (Dulatbekov 2010: 290).

Solzhenitsyn wrote that no single prisoner in the Gulag was "re-educated with the help of the department of culture and re-education" (Solženitsõn 1990: Vol II, 352). Engagement with art gave people hope, something to be involved with, and was a strategy to resist the Gulag's goal - of breaking people. To maintain their dignity, some people chose a radical uncompromising way of refusing to obey camp rules, while other people created their space within the official structures. In general, the cultural policy of the Gulag did not achieve its goal. Communists were never successful in liquidating illegal artistic activities in the camps. On the other hand, the official culture and the structures of the Gulag served as a shelter for people to distance themselves from the ideology they had to reproduce.

\section{ACKNOWLEDGEMENTS}

This research was supported by the European Union through the European Regional Development Fund (Centre of Excellence in Cultural Theory CECT). We are also in gratefully indebted to Tatiana Argunova-Low, Olga Povoroznyuk, and Norman Prell for their useful comments.

\section{NOTES}

${ }^{1}$ Russian State Archive of Russian Federation = GARF 9414.2.108,250.

${ }^{2}$ GARF 9414.1.358:1.1358,11.

${ }^{3}$ GARF 9401.1.99:14, Russian State Military Archive = RGVA 1.7:1.6,7.

${ }^{4}$ GARF 9414.1.108:13.

${ }^{5}$ GARF 9414.1.108:16, GARF 9414.1.509:25.

${ }^{6}$ The strictness of following the ideology of correction in Gulag camps, sometimes also named perekovka or reforging, varied regionally. According to informants of Norman Prell (University of Aberdeen), perekovka was quite formal in the Russian Far East, where he did his fieldwork (personal email 24.09.2012). The reason for that was probably (among others) that camps around the Magadan route were smaller and had a very concrete task - the supply of timber and taking care of the Magadan route. Also the number of criminal prisoners was much higher in penal camps of the Russian Far East. 
7 The socialist labour competition was an economic competition between work units whereas the Stakhanovite movement was focused on the individual over-fulfilling the plan or work norm. Solzhenitsyn was very skeptical of the Stakhanovite movement arguing that these persons over-fulfilled the norm only because of the additional food they received. However, the additional portion of soup or porridge did not fulfil their increased calorific requirements and Stakhanovites generally died earlier (Solženitsõn 1990).

${ }^{8}$ GARF 9414.1.719:119, 121.

${ }^{9}$ GARF 9414.1.

${ }^{10}$ It must be noted that there is hardly any archival evidence of how theatre plays were organised or costumes and decorations made, for this the memories of former inmates are the most valuable source of information.

${ }^{11}$ It seems that the loosening of the regime before the closing of the Gulag was continuous, in published memories former inmates write not only about the Estonian brass band but also about an Estonian basketball team (Kärp 1991; Surva 2010).

\section{REFERENCES}

Applebaum, Anne 2003. Gulag: A History. New York \& Toronto \& Sydney \& Auckland: Doubleday.

Bakhtin, Vladimir S. \& Putilov, Boris N. (eds.) 1994. Fol'klor i kul'turnaia sreda GULAGa. [Folklore and Cultural Environment of GULAG.] Sankt Petersburg: Kraia Moskvy.

Barnes, Steven A. 2008. The Gulag's Foundation In Kazakhstan. Global Studies Review, Vol. 4, No. 2.

Barnes, Steven A. 2011. Death and Redemption: The Gulag and the Shaping of Soviet Society. Princeton: Princeton University Press.

Bastemieva, Serik K. 2008. Ispraunitel'nye ucherezhdeniia Kazakhstana. [Corrective Institutions of Kazakhstan.] Pavlodar: Atadar.

Borodkin, Leonid I. \& Gregory, Paul \& Khlevniuk, Oleg V. (eds.) 2005. Ekonomika prinuditel'nogo truda. [The Economy of Forced Labour.] Moskva: Rosspen Press.

Dil'manov, Sergei D. 2002. Ispravitel'no-trudovye lageria NKVD-MVD SSSR na territorii Kazakhstana (30-e-50-e gody XX veka). [Corrective-Labour Camps of NKVDMVD of SU in the Territory of Kazakhstan (in the 30s-50s of the 20th Century).] Almaty: Nauka.

Dulatbekov, Nurlan O. 2009. KARLAG:Creativity in Captivity. Karagandy: Arko.

Gavrilova, Evgeniia P. 2003. Memorial Karagandy: KarLAG, kul'tura, khudozhniki. [Memorial of Karganda. Karlag, Culture, Artists.] Karaganda: TOO “Arko".

Gorcheva, Alla Iu. 1993. Detskie lageria OGPU i NKVD i pressa. [Children Camps of OGPU and NKVD and the Media.] Vestnik Moskovskogo Universiteta Seria 10 (Zurnalistika): 12-23. Moscow. 
Gregory, Paul R. 2003. An Introduction to the Economics of the Gulag. In: Paul R. Gregory \& Valery Lazarev (eds.) The Economics of Forced Labor. The Soviet Gulag. Stanford, California: Hoover Institution Press, pp. 1-21.

Gregory, Paul R. \& Lazarev, Valery (eds.) 2003. The Economics of Forced Labor. The Soviet Gulag. Stanford, California: Hoover Institution Press.

Heidegger, Martin 1962. Being and Time. New York: Harper and Row.

Ingold, Tim 2000. The Perception of the Environment. Essays on livelihood, dwelling and skill. London \& New York: Routledge.

Ivanova, Galina M. 2006. Istoriia GULAGa, 1918-1958: sotsial'no-ekonomicheskii i politiko-pravovoi aspekty. [The History of GULAG. 1918-1958: Socio-Economic and Political-Legal Aspects.] Moskva: Nauka.

Kärp, Peep 1991. Piletita külmale maale. [Without Ticket to the Cold Land.] Tallinn: Olion.

Kukushkina, Anfisa R. 2002. Akmolinskii lager' zhen “izmennikov Rodiny”: istoriia $i$ sudby. [Akmolinsk Camp for the Wives of "Traitors of Fatherland": Histories and Fates.] Karganda: B.I.

Mulhall, Stephen 1996. Heidegger and "Being and Time". London: Routledge.

Olsen, Bjørnar 2010. In Defence of Things. Archaeology and the Ontology of Objects. London \& New York \& Toronto \& Plymouth, UK: Altamira.

Perepis 2012 = Dannye perepisi naseleniia Kazakhstana 2009 goda $-v$ bezplatnom dostupe. [Census of the Population of Kazakhstan - Free Access.] http://www. brif.kz/blog/?p=1501 last accessed 08.08.2012.

Russkii... 1996 = Russkii arkhiv: Velikaia Otechestvennaia. Inostrannye voennoplennye vtoroi mirovoi voiny v SSSR. [Russian Archive: Great Fatherland War: Foreign Prisoners of War of the World War II in the Soviet Union.] Moskva: Nauka.

Shaimukhanov, Diusetai A. \& Shamuikhanova, Saule D. 1999. Karlag. Almaty: Nauka.

Solženitsõn, Aleksandr 1990. Gulagi arhipelaag. [The Gulag Archipelago.] Tallinn: Eesti Raamat.

Stark, Meinhard 2003. Frauen im Gulag: Alltag und Überleben, 1936 bis 1956. [Women in GULAG: Everyday and Survival, from 1936 to 1956.] München: Carl Hanser Verlag $\mathrm{GmbH} \& \mathrm{CO}$.

Stettner, Ralf 1996. "Archipel GULAG”: Stalins Zwangslager - Terrorinstrument und Wirtschaftsgigant: Entstehung, Organisation und Funktion des sowjetischen Lagersystems 1928-1956. [“GULAG Archipelago”: Stalin's Penal Camp - Instrument of Terror and Economic Giant: Development, Organisation and Function of Soviet Camp System 1928-1956.] Paderborn: Schöningh.

Surva, Oskar 2010. Jäine meditsiin. [Frozen Medicine.] Tartu: Eesti Ajaloo Kirjastus. Vaisberg, Boris S. 1991. Pered imenenm tvoim ... [In Front of Your Name ... .] AlmaAta: B.I. 